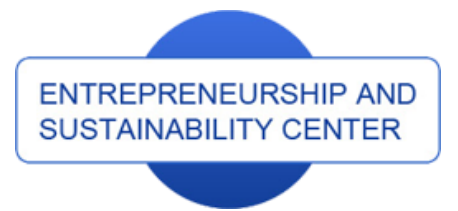

Publisher

http://jssidoi.org/esc/home enterprise

europe

network

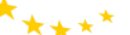

Business Support on Your Doorstep
Scopus Web of Science

\title{
EXPLORING THE KEY ISSUES AND STAKEHOLDERS ASSOCIATED WITH THE APPLICATION OF RAINWATER SYSTEMS WITHIN THE AMAZON REGION*
}

\author{
Pedro Pablo Cardoso', Andrew Swan², Ronaldo Mendes ${ }^{3}$

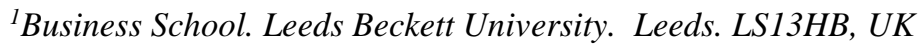 \\ ${ }^{2}$ Leeds Sustainability Institute, Leeds Beckett University, Leeds, LS2 9EN, UK \\ ${ }^{3}$ Nucleo de Meio Ambiente. Universidad Federal de Para. Belem, Brazil
}

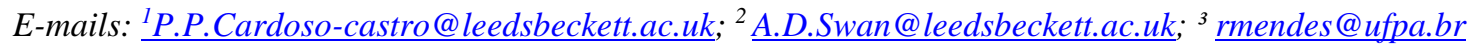

Received 10 March 2018; accepted 17 May 2018; published 30 June 2018

\begin{abstract}
* This research was supported by the project AguaSociaL an FP7-PEOPLE-2013-IRSES - Marie Curie Action "International Research Staff Exchange Scheme", Grant Agreement Number 612633
\end{abstract}
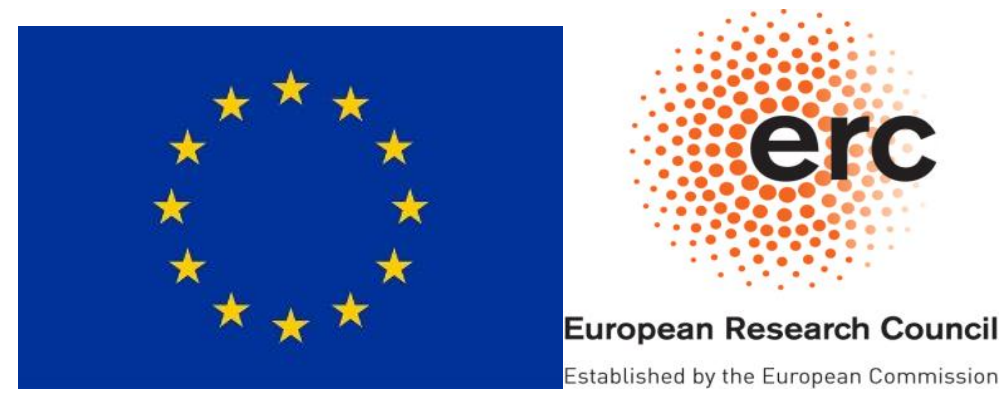


\begin{abstract}
This paper presents a case study from the Amazon region of Brazil that explores stakeholder influence over the design and implementation of rainwater harvesting systems. This explorative study is based on the application of Social Network Analysis (SNA). A series of interviews were undertaken with experts in the field and the data was coded and analysed. A stakeholder's map is presented in an attempt to summarise the study's main findings and to graphically illustrate the key stakeholder influences. The primary outcome of this exercise was the identification of the key participants and challenges associated with the implementation of rainwater harvesting systems. This exercise also highlighted the lack of interaction between some stakeholders and the canalization of decision-making powers by a small number of agencies. The scope of the study was limited to a specific geographical region and is therefore context specific. Due to the constraints of this preliminary study, the full potential of SNA has not fully been explored in this analysis. The research has identified some redundancies with regards to the management of water in this region. It has also highlighted other issues associated with 'lack of inclusion' within the decision-making process and planning for the implementation of rainwater systems. The study is considered to be novel within this geographical region. The use of such methods to map stakeholders and to graphically represent influential relationships, as well as the identification of previously unseen key actors should aid future attempts to implement rainwater harvesting schemes within this context.
\end{abstract}

Keywords: Rainwater harvesting systems; Social Network Analysis; Water management

Reference to this paper should be made as follows: Cardoso P.P.; Swan A.D. and Mendes R. 2018. Exploring the key issues and stakeholders associated with the application of rainwater systems within the Amazon Region, Entrepreneurship and Sustainability Issues 5(4): 724-735 https://doi.org/10.9770/jesi.2018.5.4(2)

JEL Classifications: I30, I38, I39

Additional disciplines: information and communication; environmental engineering

\title{
1. Introduction
}

The Amazon region experiences a number of significant challenges associated with its vast size and limited transport infrastructure. In many places, the river is the only viable transport link. These issues significantly impact the distribution and supply of key products and services, including the provision of clean water. This contributes to high local rates of waterborne disease, which are often aggravated by untreated water supply systems, inadequate/inappropriate sewage treatment facilities and open-air dumps. These issues are highlighted within local Municipal Sanitation and Management Plans which report that $91 \%$ of the municipalities have water supply systems. However, in $100 \%$ of the Amazon municipalities, the water quality does not comply with the minimum standards for human consumption as defined by the Ministry of Health. According to Brazil's National Water Agency (ANA, 2010), about 70\% of the population of the Northern region lack access to potable water. In response to these challenges, rainwater has been explored as an appropriate solution to enhance the provision of clean water to rural communities in the Amazon basin. This paper aims to explore stakeholder influence over the design and implementation of rainwater harvesting systems in this context. This explorative study is based on the application of Social Network Analysis (SNA) (see Section 3). A series of interviews were undertaken with local experts and the data then coded and analysed. A stakeholder's map is presented in Section 4 that summarises the key participants and challenges; these interactions are expounded in Section 5.

\section{Water supply problems in the Amazon Region}

\subsection{Rainwater Harvesting}

Harvesting rainwater for human consumption is not a new concept, since it has been employed by numerous civilisations over the centuries (Gnadingler, 2000; Tomaz, 2003; Kautsoyiannis et al., 2008). Contemporary methods typically utilise roofs to collect rainwater. This approach - often described as Rooftop Rainwater Harvesting (RTRWH) - is employed in many different countries. For example, Zhu et al. (2009) report that in Ganzu, one of the poorest regions in China, this type of technology serves 2.5 million people; whilst in New 


\section{The International Journal}

ENTREPRENEURSHIP AND SUSTAINABILITY ISSUES

ISSN 2345-0282 (online) http://jssidoi.org/jesi/

2018 Volume 5 Number 4 (June)

http://doi.org/10.9770/jesi.2018.5.4(2)

Zealand, $11 \%$ of the population rely on rainwater as their main source of potable water (Ministry of Health, 2006); and in Thailand, $4.3 \%$ of the urban population and $25.7 \%$ of the rural population access drinking water through the collection and storage of rainwater (ONESDB/UNCTT, 2004). Similar techniques have been documented from across the globe (UNEP, 1998); with good examples cited from Venezuela, Maldives, Turks and Caicos, Bermuda, Portugal and Greece (Oliveira, 2008). In these countries, a range of stakeholders are involved in the promotion of rainwater harvesting systems including governments, national and local authorities, international development agencies and social organizations.

Most of these documented cases utilise roofs as the primary mechanism to collect water. But there are differences in the ownership and usage arrangements. For example, some schemes are private, whilst others are publically owned; similarly, some systems are designed serve whole communities, and others just a single household.

The growing interest in the use of RTRWH has been driven by a range of factors - including problems associated with alternative water sources (e.g. contamination of groundwater sources; water system failures, maintenance and operational problems); increasing water demand in rural areas due to population growth; the increasing availability of low cost impermeable materials (e.g. tiles, veneers and galvanised iron roofing components) as a replacement for traditional straw roofs; and the emergence of increasingly economic and effective water storage devices (Fawkes, 1999).

\subsection{Rainwater harvesting in the Amazon: Belem case study}

The following case study from the Belem district highlights some of the key issues associated with the supply of potable water to riverside communities in the Amazon region. This example highlights local complexities in terms of population, and the number of organizations associated with the management of water distribution and the advancement of future solutions. This study formed part of the wider AguaSocial project which has been described in other publications (Iorio et al., 2018).

Two thirds of the Belem district is composed of river islands, in which the provision of water has not been officially registered and managed. This region suffers from the widespread degradation of water springs due to the increasing pressure of urban development. Whilst, the levels of Iron emanating from the local groundwater table are above recommended limits for human consumption. The underground aquifers are at a depth that makes them unviable for use; especially when considering the widespread distribution of population across this region - For example, the underground system in Ilha Grande is inoperative (despite its good condition) and the quality of the water delivered is questionable in terms of its Iron content (Veloso and Lopes, 2014).

Technical studies exploring potable water supplies and consumption patterns were undertaken for Belem and the wider Amazon region by UNESCO in 2004. These studies concluded that despite the vast local water resources, the main limitation for their use for human consumption is related to the qualitative aspects of the water (Aragon, 2004). Veloso (2012) investigated the consumption of water within two islands ('Ilha Grande' and 'Murutucu'); finding that $45 \%$ of these riverside populations buy water from informal distributors or 'boatmen'. These venders typically sell 20 litre barrels of untreated water that is collected either from surface or underground water sources. A further $20 \%$ of the surveyed populations reportedly consumed water directly from the river (Veloso, 2012). The study also revealed that these communities often used a combination of different sources of water; for instance, to buy water from the mainland to drink and to use water from the river for cooking. Souza (2012) documented the case of another island 'Ilha Nova', where $100 \%$ of potable water comes from rainwater collectors; whilst Fenzl et al. (2010) highlighted the unique case of two islands ('Mosqueiro' and 'Outeiro') where the water is distributed via a public aqueduct.

In consequence, rainwater has been proposed as an appropriate source for human consumption in Belem (and the Amazon in general) due to the logistical challenges experienced in this region (e.g. limited 
transport/communication infrastructure; vegetation growth, river tides, high humidity, instability of the subsoil) and the wide geographical dispersion of the rural communities that would adversely impact the viability of conventional clean water distribution networks.

Many recent rainwater collection systems employed within the Belem district, have been informal adaptations of the 'cistern based technologies' that have been implemented in other areas of Brazil. These modifications are the result of independent attempts to solve the issue of access to clean water by the riverside communities themselves (Veloso, 2012). The 'cistern-based' approach was initially implemented in the semi-arid region via the 'One Million Cisterns' program; the Semi-Arid Articulation (ASA) program has been fully implemented providing concrete cisterns for multiple users. This was implemented through partnerships with individuals, the private sector, cooperation agencies and the federal government. However, some concern has been expressed regarding the quality of water delivered by these systems (Gnadingler, 1999; Gnadingler, 2007; Joventino et al., 2010; Souza et al., 2011 and Silva et al., 2012). Furthermore, this technology has not proved to be appropriate for the bioclimatic conditions of the Amazon; and particularly for those riverside communities whose land is subject to the regular river tides and high levels of subsoil moisture and instability (Veloso, 2012).

In response to these local problems, the University of Para (UFPA) established a research project to explore the use of rainwater as a potable resource for riverside and rural communities in the region. This project sought to appropriately adapt RTRWH technologies for the inherent local conditions. This research, and its resultant technological solutions have been well documented. These studies have explored the suitability of the aforementioned local RTRWH solutions to the bioclimatic conditions of the region and the impact of these to the riverside communities in terms of their access to quality and quantity of clean water, health and economic viability (Veloso et al., 2013). The implementation process that was employed for the RTRWH approach employed slightly different mechanisms to those used for the ASA. In terms of the Belem case study, the project implementation was fully funded by the government; and involved multiple federal and local agencies, NGOs with strong influence in the region and community organizations.

However, a systematic identification of the key stakeholders and issues that affect the implementation and subsequent maintenance of the rainwater systems has not been documented. This is particularly relevant as the Amazon region is characterized by being under the jurisdiction of several offices at different administrative levels in the Brazilian government, and contains a multiplicity of communities that make this a highly complex case study in terms of policy making and socio-economic and technical interventions. In this context, this study intends to undertake an initial exploration of these complex interactions through the identification of key issues and stakeholders affecting the implementation of Rainwater systems using methods related to the analysis of complexity such as Social Network Analysis.

\section{Methodology}

Standard 'stakeholder mapping techniques' were used and enhanced by the use of Social Network Analysis (SNA). This exercise employed methodologies that have previously presented by Prell et al., (2007); Lim et al., (2010) and Lienert et al. (2013); and particularly focused upon the use of centrality measures to: assess the importance of the respective stakeholders; to anticipate possible conflictive relationships; and to enhance their participation and level of engagement with future design interventions.

The collection and analysis of data followed a two-stage process in which stakeholders were identified and classified via an iterative process that drew on a combination of methods (e.g. expert opinions, semi-structured interviews). This process followed the suggested multi-method approach by Brugha and Varavasovsky (2000) and 
Reed et al. (2009). To identify stakeholders, the respondents were asked to: 1) mention all stakeholders and issues that may influence or are affected by the implementation of rainwater systems; 2) quantify the influence each stakeholder exerts upon water infrastructure planning (Brugha and Varavasovsky, 2000). Similar stakeholders, such as community organizations, were merged into stakeholder groups, in an attempt to simplify the analysis.

A 'relational matrix' was created based on a typology in an attempt to classify stakeholders along the vertical axis (i.e. from national, federal, county, local, and off-site levels to a local, on-site level). A further typology was employed to distinguish between those agents who affect (determine) a decision/action, and those affected by this decision/action. The matrix also included those issues that had been identified in the conversations with experts and how these issues related to the different actors. This data was analyzed in UCINET (Borgatti et al., 2002). The potential influence of stakeholders upon the policy making process can be assessed in network terms via their connectivity to others. To assess this feature, we used measures of centrality as described by Freeman (1979). More specifically, we took into consideration the measurement of degree centrality, which considers the ties that each stakeholder shares directly with other stakeholders. It considers the local structure in which an actor is embedded (Akhmetshin et al., 2017; Ansell, 2003; Crona and Bodin, 2006). In policy networks, stakeholders with high degree centrality have better and more direct access to information and have considerable potential for framing the planning process. Power and importance were assessed via 'betweenness centrality' (Freeman, 1979; Ingold, 2011). Where 'betweenness centrality' calculates the number of times a stakeholder is on the path between two non-interlinked nodes. A stakeholder with high 'betweenness centrality' can thus act as a 'gatekeeper' or 'mediator'. If absent, the network would fall apart. Hence, the more central the stakeholder is, the better they are integrated into the network and can influence the planning process in resource management policy.

\section{Results and analysis}

The results of the SNA mapping exercise for the issues and stakeholders associated with the implementation of rainwater systems in the Belem district are presented in Figure 1. 
Figure 1. Identification of issues and stakeholders for the implementation of rainwater systems in the Belem District.

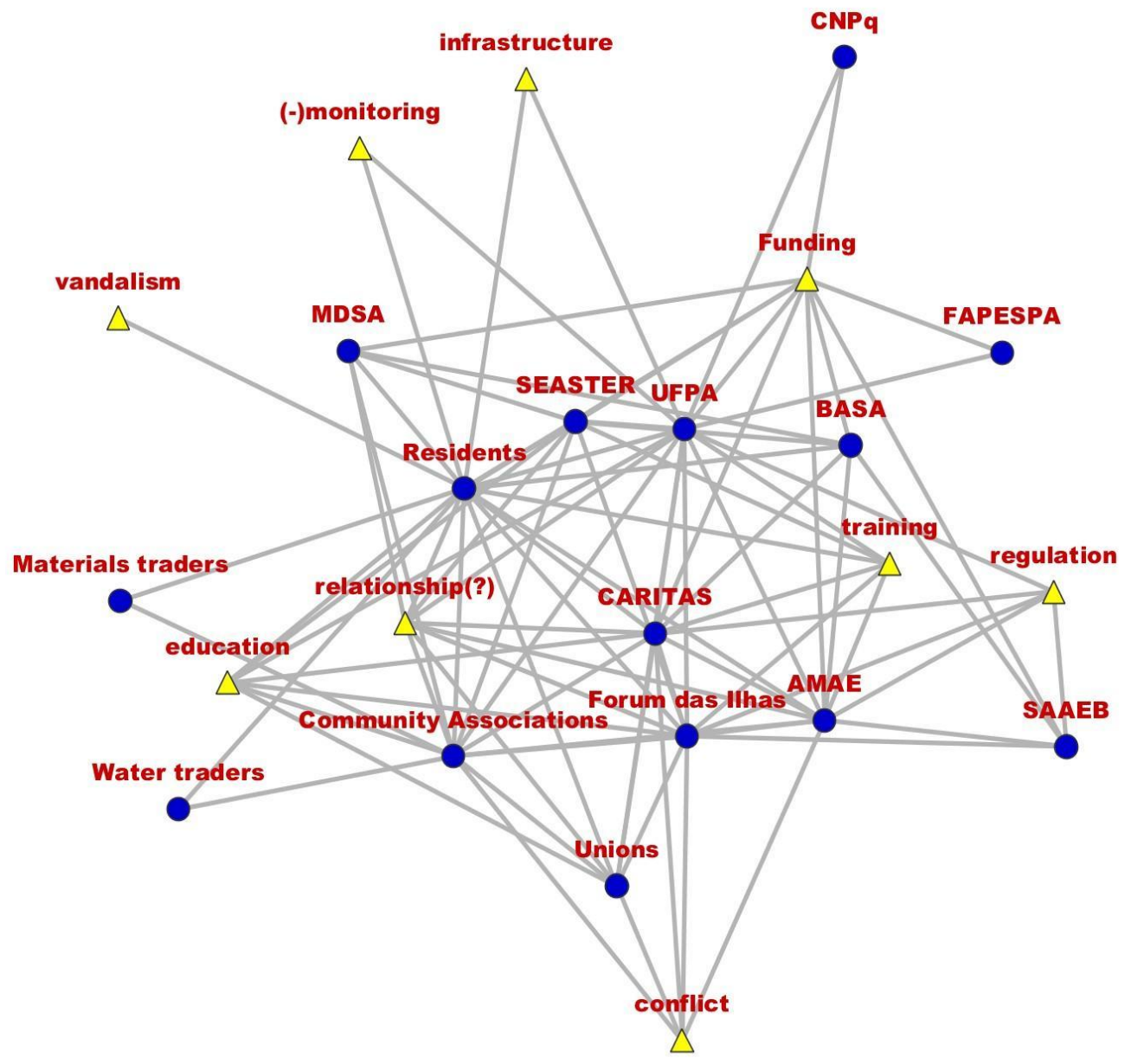

Source: Personal Elaboration

It should be noted that issues are represented on Figure 1 by triangles and the stakeholders by circles; whilst the connections between them are represented by links. The analysis of the connectivity of stakeholders and issues is guided by their 'level of centrality' and 'betweenness'; with some nodes (issues and stakeholders) ranked according to parameters such as degree and betweenness - to reflect their influence in the network and functions of brokerage. These 'nodes' were ranked (see Table 1 for Issues and Table 2 for Stakeholders) in terms of their structural position and role/function within the network, as well as their values of centrality (degree and betweenness). 
Table 1. Classification of Issues that impact the implementation of rainwater systems in the Belem District (ranked in terms of importance)

\begin{tabular}{|c|l|c|}
\hline Funding & $\begin{array}{l}\text { With the highest value of connectivity this issue is the most connected to stakeholders and seems to strongly } \\
\text { influence the future implementation of rainwater systems. The fact that the funding comes mainly from three } \\
\text { sources (Government: via public bank - BASA; Research funds - FAPESPA- and Charities) makes the } \\
\text { implementation extremely dependant and sensitive to the financial environment. }\end{array}$ \\
\hline Education & $\begin{array}{l}\text { This issue is connected to providers (UFPA, CARITAS, Forum das Ilhas) and the recipient community } \\
\text { (either directly or via several community organizations: unions, community associations). In general, the } \\
\text { education linked to rainwater systems and their implementation appears adequate, however, it is sensitive to } \\
\text { the level of education and the social dynamic of the recipient communities (e.g. peer pressure, the perception } \\
\text { of wealth). }\end{array}$ \\
\hline Conflict & $\begin{array}{l}\text { This issue was connected mainly to the different organizations acting in representation of the recipient } \\
\text { communities. Community organization is a complex issue itself, as there are more than 100 different } \\
\text { community organizations in the region with different agendas and political interests. It is noticeable that the } \\
\text { issue was not raised in relation to the multiplicity of governmental agencies involved - in many cases with } \\
\text { overlapping functions. }\end{array}$ \\
\hline Relationship & $\begin{array}{l}\text { In general, the issue relates to the brokerage function between delivery organizations and recipient } \\
\text { communities. the common perception from stakeholder interviews is that the relationship between delivery } \\
\text { organizations - at different governmental levels (e.g. MDSA - Federal government; SEASTER - County } \\
\text { government; AMAE - Municipal government) must improve and be more efficient. }\end{array}$ \\
\hline $\begin{array}{c}\text { Monitoring \& } \\
\text { Maintenance }\end{array}$ & $\begin{array}{l}\text { Despite the provision of recent training on monitoring and infrastructure maintenance. These components } \\
\text { appear deficient and unconnected to governmental agencies. Only UFPA currently perform limited } \\
\text { observations on the operational status and condition of a limited number of rainwater systems in the region - } \\
\text { aiming to develop a systematic approach to collect information to inform policy. }\end{array}$ \\
\hline
\end{tabular}

Source: Personal Elaboration

Table 2. Classification of Stakeholders that impact the implementation of rainwater systems in the Belem District (ranked in terms of importance)

\begin{tabular}{|c|c|}
\hline Residents & Their high level of centrality is easily explained as these are the direct recipients of the rainwater systems. \\
\hline CARITAS & $\begin{array}{l}\text { CARITAS (Catholic NGO) is perhaps the most influential organization at the ground level. It is well } \\
\text { connected with all the key governmental organizations at all levels (Federal, County, and Municipality) and } \\
\text { has strong links with the communities and community organizations in the region. }\end{array}$ \\
\hline UFPA & $\begin{array}{l}\text { The Federal University is a well-connected organization with strong links with governmental agents. Its } \\
\text { brokerage role is crucial as is the only agent in the network with links with federal institutions such } \\
\text { FAPESPA and CNPq. }\end{array}$ \\
\hline SEASTER & $\begin{array}{l}\text { Its high level of centrality is explained as it is the only organization and county level related to the delivery } \\
\text { and implementation of rainwater systems. They act as brokers for federal agents and point of contact and } \\
\text { coordination for local agencies. }\end{array}$ \\
\hline $\begin{array}{l}\text { Community } \\
\text { Associations }\end{array}$ & $\begin{array}{l}\text { Their centrality is explained as they act as intermediaries with final users for the implementation of rainwater } \\
\text { systems. They have high levels of complexity due their number and variety. }\end{array}$ \\
\hline $\begin{array}{l}\text { Forum das } \\
\text { Ilhas }\end{array}$ & $\begin{array}{l}\text { Its high level of connectivity relates to its function as a broker at a local level. Structurally equivalent to } \\
\text { CARITAS, it lacks the connections with organizations at the federal level. }\end{array}$ \\
\hline Unions & $\begin{array}{l}\text { Their centrality relates to the connections with local organizations at the community level. Structurally } \\
\text { equivalent to community associations }\end{array}$ \\
\hline
\end{tabular}


The International Journal
ENTREPRENEURSHIP AND SUSTAINABILITY ISSUES

ISSN 2345-0282 (online) http://jssidoi.org/jesi/

2018 Volume 5 Number 4 (June)

http://doi.org/10.9770/jesi.2018.5.4(2)

\begin{tabular}{|c|l|}
\hline Material & $\begin{array}{l}\text { These stakeholders are negatively influenced by the implementation of rainwater systems as their economic } \\
\text { activity is related and dependent on the existence of such autonomous water supply systems. Is noticeable } \\
\text { Traders \& } \\
\text { that they are not connected with any of the delivery organizations suggesting that they have not been } \\
\text { involved in any stage of the development and implementation of rainwater systems. This is reflected by } \\
\text { significant low values of centrality. }\end{array}$ \\
\hline
\end{tabular}

Source: Personal Elaboration

\section{Discussion}

This study has indicated that the key stakeholders are the Residents, UFPA, SEASTER and CARITAS. Their importance in the network is related to the fact that most of them are local to Belem and that they are key brokers for the design and implementation of local rainwater systems. These stakeholders (UFPA, SEASTER, CARITAS) also play an important role in terms of applying for public funds and liaising with other public agencies at different administrative levels (State, Federal, National). Further research is recommended to better understand their role and impact in the event of privately funded implementation of rainwater systems.

From the interviews and the SNA, it is evident that the implementation of rainwater systems is highly dependent on public funding where the NGOs (e.g. CARITAS) act mostly as delivery partners. In this sense, to increase the use of rainwater in the region - given Brazil's current economic climate - this study highlights the need to explore new sources of funding based on private capital and/or autonomously funded by the recipient communities (for instance via social entrepreneurship and/or social banking).

The study also suggests that the overlapping functions of governmental agencies at different levels (Federal, County, Municipality, Local) are not problematic at a practical level - due perhaps to accumulated expertise/experience by delivery agencies at the community/local level. However, this has the potential to be a major issue in terms of the level of ownership and autonomy that communities might have during the implementation process. This issue could be exacerbated by the current economic environment and the budget limitations of the multiple agencies involved. In this respect, the study suggests that more autonomy in the local administration with more direct access to funding sources could simplify and reduce the administrative complexity and cost of the implementation process. Here again, the adoption of private or autonomously funded initiatives could bypass and/or simplify the complexity and bureaucratic cost of the multiple overlapping agencies involved; increasing the relevance of the local agencies that could locally regulate the implementation of rainwater systems.

The second major issue at the local level is the complexity and variety of community associations (generalized in this study but with more than 100 groups in the Belem area). These groups play an important role in the recipient end of the implementation process facilitating issues such as ownership and management of the rainwater systems; the existence of unions with structural equivalence in the network may suggest that such groups could be used to bypass the role/function and complexity of the community associations to deliver rainwater systems. It is also noticeable that the strong local influence of CARITAS is derived from: their religious affiliation (Catholic charity); their contacts with different agencies at different administrative levels; and their capacity to mobilize financial resources.

In terms of the design process, it is concerning that not all the economic/social groups affected by the implementation of the rainwater systems have been involved in the different stages of development and implementation of rainwater systems in the region. It is particularly concerning, that some groups who might be negatively affected by this initiative (e.g. water and building materials traders) have been excluded from the decision-making process. It is recommended that these stakeholders are consulted with respect to any future 
expansion of this initiative; and particularly if private funding is being sought; as these stakeholders may either act as key partners or competitors if a marked based implementation process is adopted. That said, to date rainwater has proved to be more economically efficient than the distribution of bottled water.

\section{Conclusions}

It is considered that the SNA methodologies represent a useful tool to help map and analyse the complex functions and relationships between the different agents associated with this issue. However, the scope of the SNA techniques employed for this study have been constrained by data collection issues and the size of the datasets used. Limited access to information, public records and the availability of data and time have impacted the depth of this exploration. The use of more complete datasets including interviews (i.e. cascade model) involving all the agents identified as well as a comprehensive literature review of previous implementation exercises might provide a more detailed view of the issues affecting the implementation of rainwater systems in the region. This in turn should lead to a better understanding of the institutional aspects affecting the development of this initiative. At ground level, the use of interviews could more accurately identify key stakeholders in the communities who play enabling roles. This additional knowledge could enhance future attempts to secure other forms of funding.

\section{References}

Akhmetshin, E. M., Artemova, E. I., Vermennikova, L. V., Shichiyakh, R. A., Prodanova, N. A., and Kuchukova, N. M. 2017. Management of investment attractiveness of enterprises: principles, methods, organization, International Journal of Applied Business and Economic Research 15(23): 71-82.

ANA - Agência Nacional de Água. 2010, Atlas Brasil: abastecimento urbano de água: panorama nacional. Brasília: ANA; Engecorps; Cobrape, 2010. 68 p. v.1 [Online]. Available in:

http://arquivos.ana.gov.br/institucional/sge/CEDOC/Catalogo/2011/AtlasBrasil-Abastecimento UrbanodeAgua-PanoramaNacionalv1.pdf [Accessed:19th December, 2016].

Ansell, Ch. 2003, Community embeddedness and collaborative governance in San Francisco Bay area environmental movement, in: Diani, M., McAdam, D. (Eds.), Social Movements and Networks: Relational Approaches to Collective Action, Comparative Politics, Oxford.

Aragon, L. 2004, The question of water in the Amazon. In: ARAGÓN, L. E. and CLÜSENER-GODT, M. (Eds.) Issues of local and global use of water from the Amazon. Montevideo: UNESCO.

Borgatti, S.P., Everett, M.C., Freeman, L.C., 2002, UCINET for Windows: Software for Social Network Analysis. Harvard MA: Analytic Technologies.

Brugha, R. and Varvasovszky, Z. 2000, Stakeholder analysis: a review. Health Policy Plan. 15(3); 239-246.

Crona, B. and Bodin, Ö. 2006, What you know is who you know? Communication patterns among resource users as a prerequisite for comanagement, Ecol. Soc. 11(2): 7

Fawkes, A. 1999, A Modelling the performance of rainwater collection systems: towards a generalised approach, Urban Water. 1(4): 323-333.

Fenzl, N., Mendes, R. and Fernandes, L. 2010, Sustentabilidade do sistema de abastecimento de água: da captação ao consumo de água em Belém. NUMA/UFPA.

Freeman, L. 1979, Centrality in social networks: I. Conceptual clarification, Soc. Networks 1: 215-239. 
Gnadlinger, J. 1999, Apresentação Técnica de Diferentes Tipos de Cisternas, Construídas em Comunidades Rurais do Semi-árido Brasileiro, Available at: http://www.cpatsa.embrapa.br/catalogo/doc /technology/4_7_J_Gnadlinger_p.doc [Accessed: 29th November 2016].

Gnadlinger J. 2000, Coleta de água de chuva em áreas rurais. In: FÓRUM MUNDIAL DA ÁGUA. Holland. Available at: http://www.irpaa.org.br/colheita/indexb.htm [Accessed: November 25th, 2016].

Gnadlinger, J. 2007, Rumo a um padrão elevado de qualidade de água de chuva coletadas em cisternas no semi-árido brasileiro. In: SIMPOSÍO BRASILEIRO DE CAPTAÇÃO E MANEJO DE ÁGUA DA CHUVA, 6, Belo Horizonte: ABCMAC. Available at: http://www.abcmac.org.br/index.php?modulo=noticias_mat\&url_id=2 [Accessed: 30th November, 2016]

Ingold, K. 2011, Network structures within policy processes: Coalitions, power, and brokerage in Swiss climate policy. The Policy Studies Journal 39(3), 435-459

Iorio, M.; Monni, S.; Brollo, B. 2018. The Brazilian Amazon: a resource curse or renewed colonialism?, Entrepreneurship and Sustainability Issues 5(3): 438-451. https://doi.org/10.9770/jesi.2018.5.3(2)

Joventino, E., Silva, S., Rogeiro, R., Freitas, G., Ximenes, L. and Moura, E. 2010. Comportamento da diarreia infantil antes e após o consumo de água pluvial em município do semi-árido brasileiro. Texto Contexto Enferm, Florianópolis, n. 19, out.- dez. p. 691-699.

Kautsoyiannis, D., Zarkadoulas, N., Angelakis, A. and Tchobanglosu, G. 2008. Urban Water Management in Ancient Greece: Legacies and Lessons. Journal of Water Resources Planning and Management - ASCE. [Online]. Available at: http://www.itia.ntua.gr/en/docinfo/750 [Accessed: 3rd December, 2016].

Lienert J., Schnetzer, F. and Ingold, K. 2013. Stakeholder analysis combined with social network analysis provides fine-grained insights into water infrastructure planning processes. Journal of Environmental Management 125: 134-148.

Lim, S., Quercia, D. and Finkelstein, A. 2010. StakeSource: Harnessing the power of crowdsourcing and social networks in stakeholder analysis. In Proceedings of the IEEE 32nd International Conference on Software Engineering,

Ministry of Health 2006. A Summary of the Annual Review of the Microbiological and Chemical Quality of Drinking-Water in New Zealand 2005. 15 p. Ministry of Health, Wellington, New Zealand.

ONESDB/UNCTT. 2004. Office of the National Economic and Social Development Board; United Nations Country Team in Thailand. Thailand Millennium Development Goals Report 2004. 92 p. Bangkok, Thailand

Oliveira V. 2015. Aproveitamento de agua de chuva para consumo humano em areas rurais de municípios isolados pela seca no estado do Amazonas. Master Thesis. Universidade Federal do Para. Maestrado em processos construtivos e saneamento urbano.

Prell C., Hubacek, K. and Reed, M. 2007. Stakeholder analysis and social network analysis in natural resource management. Society Nat. Resources 22(6), 501-18.

Reed M., Graves, A., Dandy, N., Posthumus, H., Hubacek, K., Morris, J., Prell, C., Quinn, C.H. and Stringer, L. 2009. Who's in and why? A typology of stakeholder analysis methods for natural resource management, J. Environ. Manage. 90(5); 1933-1949.

Silva, C., Heller, L. and Carneiro, M. 2012. Cisternas para armazenamento de água de chuva e efeito na diarreia infantil: um estudo na área rural do semiáridode Minas Gerais, Engenharia Sanitária e Ambiental. 17(4 . out./dez.): 393-400.

Souza C. 2012. Sistema de captação de água de chuva para atendimento à populações tradicionais em Ilhas de Belém: Avaliação de impactos decorrentes. Belém. (Relatório Técnico Final, Processo: 576901/2088-3).

Souza S., Montenegro, S., Santos, S., Pessoa, S. and Nobrega, R. 2011. Avaliação da Qualidade da Água e da Eficácia de Barreiras Sanitárias em Sistemas para Aproveitamento de Águas de Chuva, Revista Brasileira de Recursos Hídricos 16(3 - jul/set): 81-93.

Veloso N. 2012. Aproveitamento da água da chuva e desenvolvimento local: o caso das ilhas de Belém. Master Thesis. UFPA, Belem.

Veloso N.,Goncalves, C.,Mendes, R.,Sobrinho, M., da Costa, T. And Oliveira, D. 2013. A pós-graduação e a sustentabilidade do abastecimento de comunidades ribeirinhas na Amazônia por meio de água de chuva: da concepção à ação, Revista Brasileira de Pos 
Graduacao 10 (21): 761-791.

Veloso N. and Lopes, R. 2014. Aproveitamento da Água da Chuva na Amazônia: Experiências nas Ilhas de Belém/PA, Revista Brasileira de Recursos Hídricos 19(1 -Jan/Mar): 229-242

Zhu Q. And Yuanhong. L. 2009. A sustainable way for integrated rural development in the mountainous area in China. In VII Simpósio Brasileiro de Captação e Manejo de Água de Chuva, Caruaru-PE. Caruaru-PE, ABCMC.

\section{Acknowledgements}

This research was supported by the project AguaSociaL an FP7-PEOPLE-2013-IRSES - Marie Curie Action "International Research Staff Exchange Scheme", Grant Agreement Number 612633
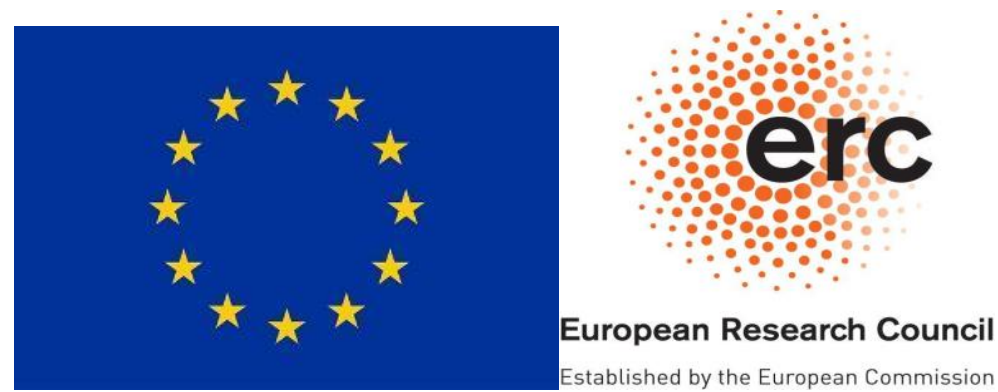
The International Journal

ENTREPRENEURSHIP AND SUSTAINABILITY ISSUES

ISSN 2345-0282 (online) http://jssidoi.org/jesi/

2018 Volume 5 Number 4 (June)

http://doi.org/10.9770/jesi.2018.5.4(2)

Short biographical note about the contributors at the end of the article (name, surname, academic title and scientific degree, duties, research interests):

Pedro Pablo CARDOSO-CASTRO is a Senior Lecturer at Leeds Beckett University. He has experience as a manager and consultant both, at national and international level and its research interest is related with the application of complexity and systems thinking in management, governance, entrepreneurship, leadership and business and social development. His research explores the application of Strategy (military), Cybernetics, Complexity and Systems Thinking in business and social innovation initiatives. In particular, the selforganizing behaviour of business networks; the dynamic of networks in internationalization processes; the management of such networking behaviour; the nature of emergent organizational structures and the enterprise architecture arising from internationalization practices, dynamic networking and the interaction of the bottom-up and top-down communications and control mechanisms in self-organizing environments and its influence in the strategizing process.

ORCID ID: orcid.org/ 0000-0002-5665-4471

Andrew SWAN is a Senior Lecturer with over 20 years of postgraduate experience. He has worked in both industry and academia on a range of domestic and international engineering projects, including an extended VSO placement as a researcher at the Institute of Water and Sanitation Development, Zimbabwe, Africa. Dr Swan has secured recent funding awards from the EU FP7, Innovate UK, and Erasmus+ funding mechanisms. This funding has supported formal collaborations with four Universities in Brazil, Italy and Spain and three UK based companies. Dr Swan has served as Principal Investigator (PI) on six research/enterprise projects with a combined value of $£ 404,000$. Dr Swan's research activities focus upon some of the key water-related challenges and issues in developing regions of the Global South, including the operational unreliability of water infrastructure. He has recently undertaken projects in Brazil, Gambia, India, Malawi and Sierra Leone.

ORCID ID: orcid.org/ 0000-0001-7325-8051

Ronaldo Lopes Rodrigues Mendes graduated in Geology (1997), Master in Geophysics (2000), PhD in Sustainable Development in the Humid Tropic (2005) at UFPA. Adjunct Professor at UFPA, courses on subjects related to water supply (Underground water, Rain water). Works within Graduate Programs in "Management of Natural Resources and Local Development" and Civil Engineering, and the undergraduate course in Sanitary and Environmental Engineering.

ORCID ID: orcid.org/ 0000-0002-5584-8688

Register for an ORCID ID:

https://orcid.org/register

Copyright (C) 2018 by author(s) and VsI Entrepreneurship and Sustainability Center

This work is licensed under the Creative Commons Attribution International License (CC BY).

http://creativecommons.org/licenses/by/4.0/

(c) (†) Open Access 